\title{
床版と桁の偏心結合を考慮した曲線桁橋の解析 \\ ANALYSIS OF CURVED GIRDER BRIDGES CONSIDERING ECCENTRIC CONNECTION BETWEEN A DECK PLATE AND GIRDERS
}

\author{
大塚久哲*.吉村虎蔵**・彦坂 熙***.平田勝啓**** \\ By Hisanori OTSUKA, Torazo YOSHIMURA, \\ Hiroshi HIKOSAKA and Katsuyoshi HIRATA
}

\section{1. 序言}

近年, 曲線桁橋の架設が随所に見受けられるが,この 種構造物の設計計算にあたっては, 従来主として曲線直 交異方性板理論 ${ }^{12}$ (6) ・曲線格子桁理論 ${ }^{7} \sim$ 11) ・薄肉曲線は り理論 ${ }^{12 \sim}$ 18) などが適用されている．このうち前二者の 理論による解法は，床版と桁とが一体的に構筑される曲 線析橋を, 曲線格子構造あるいは曲線直交異方性板とみ なし,計算に必要な等伍剛度を算定のうえ,置換したそれ ぞれの解析モデルの変位・断面力を求めるものである. したがって桁間隔が大きい構造あるいは構成要素の多い 構造では, 有効幅や等価剛度の算定が問題となることが ある. また, 板理論では主桁の水平面内曲げや曲げ叔じ りを考慮することができないし，格子桁理論では通常主 析の水平面内曲げを考慮せず, 横析・横構などの影響に よる主桁フランジの付加応力は別途に算定されているよ らである ${ }^{34}$. 一方, 薄肉曲線はり理論は, 多主析橋を 1 本の断面形状不変のはりと仮定しており, 構造物が大型 化・薄肉化している現在では必ずしも綮密な解法とはい い難い場合もあり，また横桁には無関係に計算を進める ため横桁の応力算定が直接できないなどの難点がある.

本研究は単純曲線桁橋について, これを扇形床版・曲 線主析および横桁の 3 構成要素からなる板・桁複合構造 物とみて, これら構成要素間 (床版と主桁, 主桁と横桁) の偏心結合を考慮した曲線桁橋の解析法を提示するもの である. 本解析法法扇形床版の剛性方程式を有限帯板法 (FSM) により，曲線主桁のそれをフーリエ級数展開に より，横桁のそれを有限要素法 (FEM) により求めて, 結合法 ${ }^{19)}$ 23) を用いて三者を一体化して解析する手法を 用いる.これによれば前記諸理論では解明が不十分であ

${ }^{*}$ 正会員 工修 九州大学助手 工学部土木工学科

** 正会員 工博 九州大学教授 工学部土木工学科

*** 正会員 工博 九州大学助教授 工学部士木工学科

**** 学生会員 九州大学大学院修士課程 工学部土木工学科
った各構成要素間の力学的相互作用を把握できる．また 曲線析橋においては, 横構・対傾構も重要な構成要素で あるが，これらの剛性方程式をFEMにより求めれば， 同じく結合法を用いてこれらと曲線主桁との偏心結合を 考慮した解析が行える.

扇形床版とそれを支持する桁とからなる構造を板・桁 複合構造として解析寸る研究のおもなものには, 米沢 ${ }^{24)}$, 山崎 ${ }^{25)}{ }^{27)}$, 著者 ${ }^{28), 29)}$, 韮沢 ${ }^{30)}$ および D.N. Buragohain ら ${ }^{31}$ の諸研究がある.このうち文献 24) 29)の 研究では, 床版の中立面と桁の中立軸は同一平面上にあ ると仮定され，文献 30) では，扇形沐版と曲線主桁の偏 心結合が考虑されているが，横桁を有する構造は対象々 されていない，また文献 31) では，3構成要素間の偏心 結合が考慮されているが，曲線主桁の曲げねじりを無視 して剛性方程式が誘導されている.

本論の数值計算例では, 曲線析橋の模型実験結果 ${ }^{6), 31)}$ との比較により本解析法の精度が検討され, さらに 2 円 弧辺に曲線主桁を有する扇形床版の, 弾性挙動に及ぼす 曲線主桁の剛度および偏心結合の影響などが取り扱われ ている.

\section{2. 解 析 法}

(1) 扇形床版と曲線 主析の剛性行列と たわみ性行列

扇形床版を任意の同心 円弧でいくつかの扇形帯 板要素に分割し，円筒座 標系と変位の方向を,

Fig. 1 のように定義す る. 面内変位 $u, v$ と面外 変位 $w$ の変位関数は,

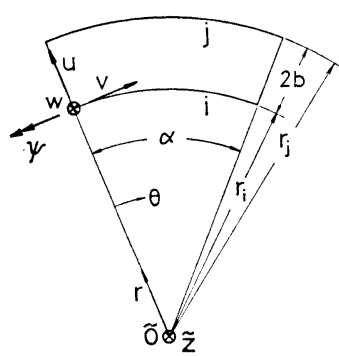

Fig. 1 A Strip for Sector Plate 
直線辺での境界条件 (単純支持)を満足するように円周方 向には級数展開し, 半径方向には多項式近似を行うと, 次式のように仮定できる.

$$
\begin{aligned}
& u=\sum_{m=1,2, \cdots}^{\infty}\left[\left(1-\frac{R}{2}\right) S_{m} \frac{R}{2} S_{m}\right]\left\{u_{i m} u_{j m}\right\}^{T} \\
& v=\sum_{m=1,2, \cdots \ldots \ldots \ldots \ldots \ldots \ldots \ldots(1 \cdot \mathrm{a})}^{\infty}\left[\left(1-\frac{R}{2}\right) C_{m} \frac{R}{2} C_{m}\right]\left\{v_{i m} v_{j m}\right\}^{T} \\
& \ldots \ldots \ldots \ldots \ldots \ldots \ldots \ldots(1 \cdot \mathrm{b}) \\
& w=\sum_{m=1,2, \cdots}^{\infty}\left[\left(1-\frac{3}{4} R^{2}+\frac{R^{3}}{4}\right) S_{m} b\left(R-R^{2}+\frac{R^{3}}{4}\right) S_{m}\right. \\
& \left.\left(\frac{3}{4} R^{2}-\frac{R^{3}}{4}\right) S_{m} b\left(\frac{R^{3}}{4}-\frac{R^{2}}{2}\right) S_{m}\right] \\
& \cdot\left\{w_{i m} \psi_{i m} w_{j m} \psi_{j m}\right\}^{T} \ldots \ldots \ldots \ldots \ldots(1 \cdot \mathrm{c})
\end{aligned}
$$

ここに, $R=\left(r-r_{i}\right) / b, 2 b$ : 帯板要素の幅, $r_{i}$ : 節線 $i$ の 曲率半径, $S_{m}=\sin k_{m} \theta, C_{m}=\cos k_{m} \theta, k_{m}=m \pi / \alpha, m$ : 調和項数, $\alpha$ : 中心角, $u_{i m}$ : 節線 $i$ 上の変位 $u$ の第 $m$ 項フーリエ展開係数 (他も同様), 肩字 $T$ は転置を示す. 式（1）を用いてひずみ・曲率と変位の関係式，およびモ ーメント・平面応力と変位の関係式を求め, ポテンシャ ルエネルギー最小の原理を適用すれば扇形帯板要素の剛 性方程式をうる(文献 5)，32）参照).

次に曲線主桁要素のうち Fig. 2 に示すような 1 本の 曲線桁を取り出し, これを断面形状不変の薄肉曲線はり と考える. いま曲線桁の中立点 $o$ を原点とする座標系を 導入するとき, 中立点の変位 $u^{o}, v^{o}, w^{o}, \psi^{0}$ と中立点を 連ねた軸 (以下中立線と略称) の変形に関する幾何学量 との関係は, 次式で与えられる ${ }^{17)}$.

$$
\left\{\varepsilon_{L}\right\}=\left\{\begin{array}{c}
\varepsilon_{t} \\
\kappa_{t} \\
\kappa_{h} \\
\kappa_{w} \\
\kappa_{s}
\end{array}\right\}=\left\{\begin{array}{l}
\frac{1}{R_{o}}\left(\frac{d v^{o}}{d \theta}+u^{o}\right) \\
-\frac{1}{R_{o}^{2}}\left(\frac{d^{2} w^{o}}{d \theta^{2}}+R_{o} \psi^{o}\right) \\
\frac{1}{R_{o}^{2}}\left(\frac{d^{2} u^{o}}{d \theta^{2}}-\frac{d v^{o}}{d \theta}\right) \\
\frac{1}{R_{o}^{2}}\left(\frac{1}{R_{o}} \frac{d^{2} w^{o}}{d \theta^{2}}-\frac{d^{2} \psi^{o}}{d \theta^{2}}\right) \\
\frac{1}{R_{o}}\left(\frac{d \psi^{o}}{d \theta}-\frac{1}{R_{o}} \frac{d w^{o}}{d \theta}\right)
\end{array}\right\}
$$

ここに， $\varepsilon_{t}, \kappa_{t}, \kappa_{h}, \kappa_{w}$ および $\kappa_{s}$ は，それぞれ中立線の 伸び率， $y-z$ 面内における曲率， $x-y$ 面内に打ける初期 曲率からの曲率の変化, 曲げねじれ率およびねじれ率で あり, $R_{o}$ は中立線の初期曲率半径, $\left(u^{o}, v^{o}, w^{o}\right)$ は $(x, y, z)$ 軸方向の変位, $\psi^{\circ}$ は $\theta$ の正の方向に向かっ て左まわりを正とするねじれ角である。曲線桁の中立点 $o$ と, その鉛直上方に位置する扇形床版の中立面上の点 $U$ との距離を $e_{L}$ とする (Fig. 5 参照). 曲線桁と扇形 床版は点 $U$ で剛結され, かつ変形を微小と考えれば点 $o$ の変位 $u^{o}, v^{o}, w^{o}, \psi^{o}$ と点 $U$ の変位 $u, v, w, \psi^{\prime}$ の間 には次の関係が成立する。

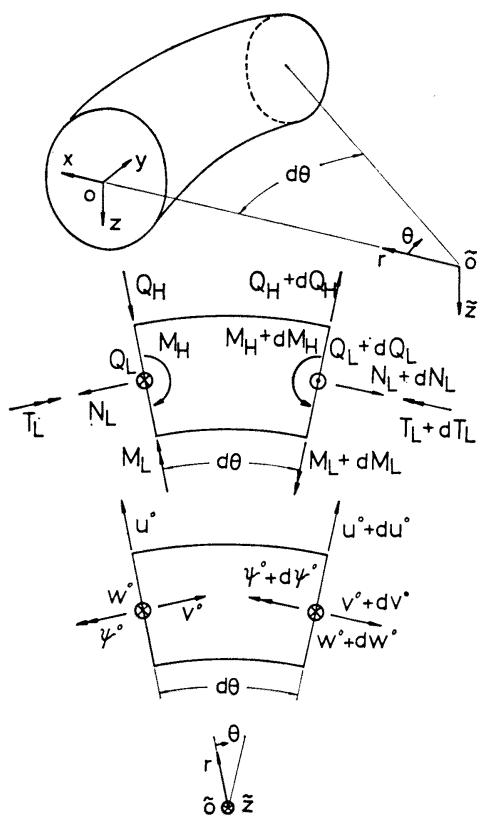

Fig. 2 A Curved Girder

$$
\left.\begin{array}{l}
u^{o}=u-e_{L} \psi, v^{o}=v-\frac{e_{L}}{R_{o}} \frac{\partial w}{\partial \theta}, \\
w^{o}=w, \psi^{o}=\psi
\end{array}\right\}
$$

式 (3) を用いて式 (2) の曲線桁のひずみベクトル $\left\{\varepsilon_{L}\right\}$ を, 床版の中立面上の変位で表わせば式（4）をうる.

$$
\left\{\varepsilon_{L}\right\}=\left\{\begin{array}{l}
\varepsilon_{t} \\
\kappa_{t} \\
\kappa_{h} \\
\kappa_{w} \\
\kappa_{s}
\end{array}\right\}=\left\{\begin{array}{l}
\frac{1}{R_{o}}\left(\frac{d v}{d \theta}-\frac{e_{L}}{k_{o}} \frac{d^{2} w}{d \theta^{2}}+u-e_{L} \psi^{\prime}\right) \\
-\frac{1}{R_{o}^{2}}\left(\frac{d^{2} w}{d \theta^{2}}+R_{o} \psi\right) \\
\frac{1}{R_{o}^{2}}\left(\frac{d^{2} u}{d \theta^{2}}-e_{L} \frac{d^{2} \psi}{d \theta^{2}}-\frac{d v}{d \theta}+\frac{e_{L}}{R_{o}} \frac{d^{2} w}{d \theta^{2}}\right) \\
\frac{1}{R_{o}^{2}}\left(-\frac{d^{2} \psi}{d \theta^{2}}+\frac{1}{R_{o}} \frac{d^{2} w}{d \theta^{2}}\right) \\
\frac{1}{R_{o}}\left(\frac{d \psi}{d \theta}-\frac{1}{R_{o}} \frac{d w}{d \theta}\right)
\end{array}\right\}
$$

1 本の曲線桁の中立線に関する断面力 $\{N\}$ とひずみべ クトル $\left\{\varepsilon_{L}\right\}$ との関係は次式で与えられる ${ }^{17)}$.

$$
\begin{aligned}
\{N\}= & \left\{\begin{array}{l}
N_{L} \\
M_{L} \\
M_{H} \\
M_{w} \\
T_{L S}
\end{array}\right\}=\left[\begin{array}{ccccc}
E_{L} A_{L} & 0 & 0 & 0 & 0 \\
0 & E_{L} I_{x} & E_{L} I_{x z} & E_{L} C_{x} & 0 \\
0 & E_{L} I_{x z} & E_{L} I_{z} & E_{L} C_{z} & 0 \\
0 & E_{L} C_{x} & E_{L} C_{z} & E_{L} C_{w} & 0 \\
0 & 0 & 0 & 0 & G_{L} J_{L}
\end{array}\right] \\
& \cdot\left\{\begin{array}{l}
\varepsilon_{t} \\
\kappa_{t} \\
\kappa_{h} \\
\kappa_{w} \\
\kappa_{s}
\end{array}\right\}=\left[D_{L}\right]\left\{\varepsilon_{L}\right\}
\end{aligned}
$$

ここに, $N_{L}, M_{L}, M_{H}, M_{w}$ および $T_{L S}$ は，それぞれ 軸力, $x$ 軸, $z$ 軸まわりの曲げモーメント, そりモーメ 


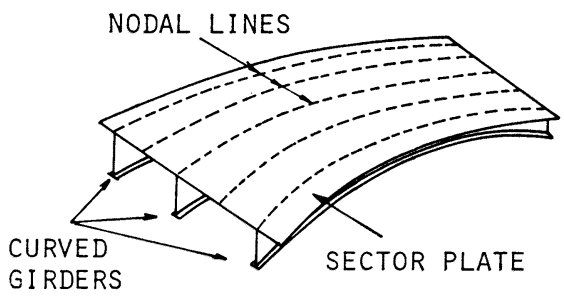

Fig. 3 Nodal Lines

ントおよび純ねじりモーメント. $E_{L}$ および $G_{L}$ は，それ ぞれヤング係数およびせん断弾性係数. $A_{L}, I_{x}, I_{z}, I_{x z}$, $C_{x}, C_{z}, C_{w}$ および $J_{L}$ はすべて断面定数で, それぞれ $o$ に関する等価断面積, $x$ 軸, $z$ 軸に関する断面二次モ ーメント, $x-z$ 軸に関する断面相乗モーメント, $x$ 軸, $z$ 軸まわりのそりに関する相乗モーメント (Sectorial Product of Inertia)，そりねじり定数および純ねじり定 数である.

いま, Fig. 3 に示すように曲線主桁と扇形床版の接 合線上に帯板要素の節線を配置すれば，接合線での床版 の中立面の変位は次式のように節線の変位で表わせる.

$$
\left.\begin{array}{l}
u=\sum_{m=1,2, \ldots}^{\infty} u_{i m} S_{m}, v=\sum_{m=1,2, \ldots}^{\infty} v_{i m} C_{m}, \\
w=\sum_{m=1,2, \cdots}^{\infty} w_{i m} S_{m}, \psi=\sum_{m=1,2, \cdots}^{\infty} \psi_{i m} S_{m}
\end{array}\right\}
$$

ゆえに式 (4)，(6) から曲線桁のひずみベクトル $\left\{\varepsilon_{L}\right\}$ は節線 $i$ の変位を用いて次のように表わすことができ る.

$$
\left\{\varepsilon_{L}\right\}=\sum_{m=1,2, \cdots}^{\infty}\left[A_{m}\right]\left\{W_{m}\right\}
$$

ここに, $\left\{W_{m}\right\}=\left\{u_{i m} v_{i m} v_{i m} \psi_{i m}\right\}^{T}$ で $\left[A_{m}\right]$ の具体的 内容については付録 A-1 参照. 1 本の曲線桁のひずみ エネルギーは，

$$
\begin{aligned}
V= & \frac{1}{2} \int_{0}^{\alpha}\{N\}^{T}\left\{\varepsilon_{L}\right\} r d \theta=\sum_{m=1,2, \cdots}^{\infty} \frac{1}{2}\left\{W_{m}\right\}^{T} \\
& \cdot\left(\int_{0}^{\alpha}\left[A_{m}\right]^{T}\left[D_{L}\right]\left[A_{m}\right] r d \theta\right)\left\{W_{m}\right\} \cdots(8)
\end{aligned}
$$

で表わされるから，ポテンシャルエネルギー最小の原理 より曲線桁の第 $m$ 項の剛性行列は次式で求められる.

$$
\left[S_{g m}\right]=\int_{0}^{\alpha}\left[A_{m}\right]^{T}\left[D_{L}\right]\left[A_{m}\right] r d \theta .
$$

( $\left[S_{g m}\right]$ の具体的内容については 付録 A-2 参照)

したがって扇形帯板要素の剛性方程式と式 (9) で与えら れる曲線桁の剛性行列を重ね合わせれば, 扇形床版と曲 線主桁からなる構造 (ここでは基本構とよぶ) の第 $m$ 項 の剛性方程式が次のようにえられる.

$$
\left[S_{m}\right]\left\{\delta_{m}\right\}=\left\{P_{m}\right\}
$$

上式はまた次式で表現できる.

$$
\left\{\hat{\delta}_{m}\right\}=\left[F_{m}\right]\left\{P_{m}\right\}
$$

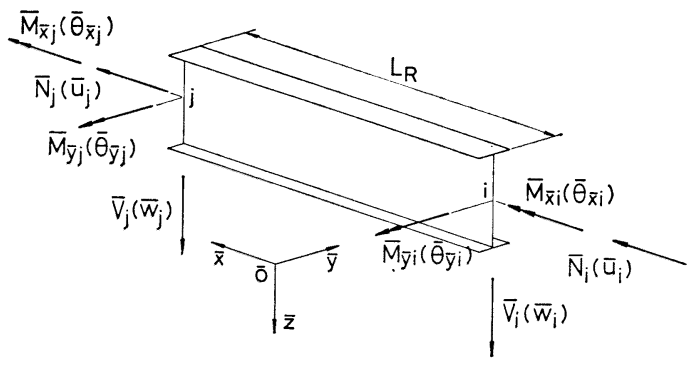

Fig. 4 A Cross Beam

$$
\begin{gathered}
\left\{\delta_{m}\right\}=\left\{u_{1 m} v_{1 m} w_{1 m} \psi_{1 m} u_{2 m} v_{2 m} w v_{2 m} \psi_{2 m} \cdots\right\}^{T} \\
\left\{P_{m}\right\}=\left\{P_{(u)_{1 m}} P_{(v)_{1 m}} P_{(w)_{1 m}} P_{(\psi)_{1 m}} P_{(u)_{2 m}}\right. \\
\left.P_{(v)_{2 m}} P_{(w)_{2 m}} P_{(\psi)_{2 m}} \cdots\right\}^{T}
\end{gathered}
$$

$\left[S_{m}\right],\left[F_{m}\right]$ はそれぞれ基本構の節線剛性行列, 節線た わみ性行列であり, $\left\{\delta_{m}\right\}$ は変位ベクトル, $\left\{P_{m}\right\}$ は荷 重ベクトルである.

\section{（2）横杕の剛性行列}

3 次元立体骨組では 1 節点 6 自由度を有するが, 曲線 桁橋の横桁は, その力学的性状から判断して Fig. 4 に 示す 1 節点 4 自由度の直線部材として扱らことにすれ ば，その剛性方程式をFEM により次式で表わすことが できる.

$$
\begin{aligned}
& \left\{\bar{N}_{i} \bar{V}_{i} \bar{M}_{\bar{y} i} \bar{N}_{j} \bar{V}_{j} \bar{M}_{\bar{y} j} \bar{M}_{\bar{x} i} \bar{M}_{\bar{x} j}\right\}^{T} \\
& \quad=\left[\begin{array}{cc}
{\left[K_{a}\right]} & 0 \\
0 & {\left[K_{b}\right]}
\end{array}\right]\left\{\bar{u}_{i} \bar{w}_{i} \bar{\theta}_{\bar{y} i} \bar{u}_{j} \bar{w}_{j} \bar{\theta}_{\bar{y} j} \bar{\theta}_{\bar{x} i} \bar{\theta}_{\bar{x} j}\right\}^{T}
\end{aligned}
$$

ここに, $\bar{N}, \bar{V}, \bar{M}_{\bar{y}}$ および $\bar{M}_{\bar{x}}$ はそれぞれ軸力, せん 断力, 曲げモーメントおよびねじりモーメント， $\bar{u}, \bar{w}$, $\bar{\theta}_{\bar{y}}$ および $\bar{\theta}_{\bar{x}}$ はそれぞれ軸方向変位, 鉛直たわみ, たわ み角およびねじれ角であり，添字 $i$ と $j$ は節点番号を 示す ( $\left[K_{a}\right],\left[K_{b}\right]$ の具体的内容については 付録 $\mathbf{A}-\mathbf{3}$ 参照).

\section{（3）扇形床版・曲線主桁系と横析の結合}

扇形床版・曲線主桁よりなる基本構汇荷重がかかる系 を基本系と名づける.この基本系では，曲線主桁の剛性 方程式がフーリエ級数展開により求められて, FSM で 誘導された扇形床版の剛性方程式に重衫合わされるた め, 通常の FSM の解析手順で所要の応力・変位を解く ことができる.

横析を有する場合の解析手法としては, 次の 3 種の方 法が考えられよう。（1）級数展開された節線の変位式 （6）を用いて，横桁の変位を表示し，ポテンシャルエネ ルギー最小の原理から横桁の剛性方程式を誘導し, しか るのち, 基本構と横桁の剛性行列を重㸚合わせて与系を 解析する. (2) 基本構の節線たわみ性行列から 横桁の 結合点における変位と力の関係式（基本構の節点たわみ 
性行列) を誘導し，その逆行列 (基本構の節点剛性行列) と, 有限要素法により導いた横栴の剛性行列（式 (12)) とから, 結合点の結合力を求める. 外荷重と結合力を基 本構に作用させて与系を解析する. (3) (2) と同様の 考え方であるが，横析の剛性行列と基本構の節点たわみ 性行列とから直接, 結合力を求める.

このうち，方法 (1) は系全体の剛性行列からただちに 変位を求める手法であって, 解析の流れは一貫している が，基本構の節線剛性方程式を解く場合に利用できる各 調和項数ごとの独立の計算を，この方法では進めること ができない，したがって，方法 (2)，(3)に比べて，演 算労力が一般に増えるように思われる. 方法 (2)，(3) は同じ考え方に立つ解析手法であるが，両者を比較する と, 計算手順は (3) の方がやや少なくてすむから, 本論 文では方法 (3)により横枌を有する曲線桁橋の解析を進 める. 以下に結合力の求め方を記す.

Fig. 5 (a) は基本構と横桁の結合関係の一例を, $x-z$ 面内の断面図で示したものである. ここに，Uは床版 と曲線主桁との結合点 (扇形帯板要素の節線の位置に相 当), $o$ は曲線主桁の中立点, $\bar{o}$ は曲線主桁と横枌との 結合点（横桁の節点に相当）を示す. 前述のごとく $U$ は $o$ の鉛直上方に位置し, その距離を $e_{L}$ としており,

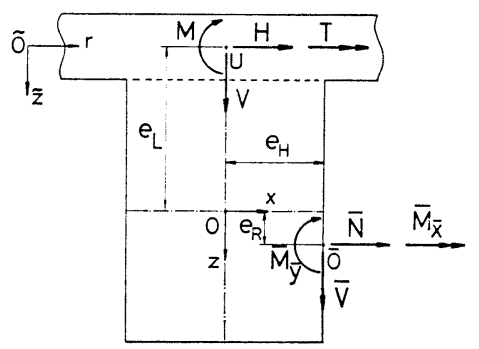

(a)

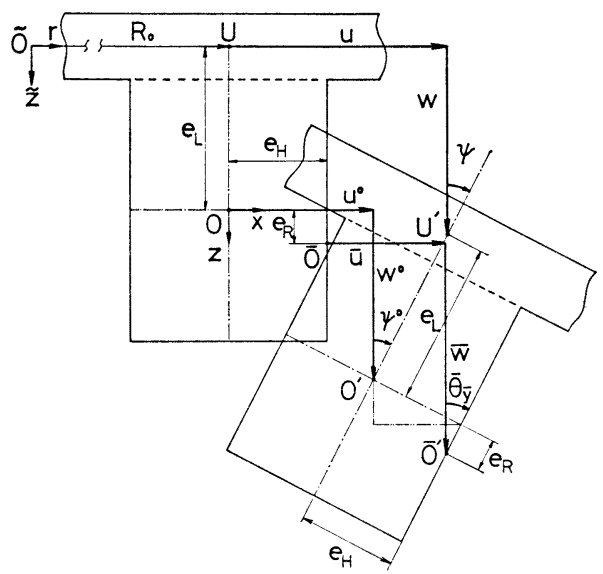

(b)

Fig. 5 Connecting Forces and Displacements at Connecting Points
さらに $o$ と $\bar{o}$ 水平距離, 鉛直距離をそれぞれ $e_{H}, e_{R}$ とする. このとき横桁との結合点 $\bar{o}$ に働く力（以下節点 力とよぶ） $\bar{N}, \bar{V}, \bar{M}_{\bar{y}}, \bar{M}_{\bar{x}}$ とこれと等価な $U$ に働く力 (以下節線力とよぶ) $H, V, M, T$ との関係は次式で与 えられる。

$$
\left\{\begin{array}{l}
H \\
V \\
M \\
T
\end{array}\right\}=\left[\begin{array}{cccc}
1 & 0 & 0 & 0 \\
0 & 1 & 0 & 0 \\
-\left(e_{L}+e_{R}\right) & e_{H} & 1 & 0 \\
0 & 0 & 0 & 1
\end{array}\right]\left\{\begin{array}{l}
\bar{N} \\
\bar{V} \\
\bar{M}_{\bar{y}} \\
\bar{M}_{\bar{x}}
\end{array}\right\}
$$

ここに一つきの文字は横桁の諸量を,一なしは床版の諸 量を示す. 次にFig. 5 (b) は任意の荷重を受けたとき の曲線主桁の変形図を Fig. 5 (a) と同様に $x-z$ 面内 で示したものであるが，非載荷時の点 $U, o, \bar{o}$ が変形 後, $U^{\prime}, o^{\prime}, \bar{o}^{\prime}$ に位置すると考える. このとき点 $U$ の 変位 (以下節線変位とよぶ) $u, w, \psi, \varphi$ と $\bar{o}$ の変位 (以 下節点変位とよぶ） $\bar{u}, \bar{w}, \bar{\theta}_{\bar{y}}, \bar{\theta}_{\bar{x}}$ の間には，次の関係式 が成立する.

$$
\left\{\begin{array}{c}
u \\
w \\
\psi \\
\varphi
\end{array}\right\}=\left[\begin{array}{cccc}
1 & 0 & \left(e_{L}+e_{R}\right) & 0 \\
0 & 1 & -e_{H} & 0 \\
0 & 0 & 1 & 0 \\
0 & 0 & 0 & 1
\end{array}\right]\left\{\begin{array}{c}
\bar{u} \\
\bar{w} \\
\bar{\theta}_{\bar{y}} \\
\bar{\theta}_{\bar{x}}
\end{array}\right\}
$$

ただし $\varphi, \bar{\theta}_{\bar{x}}$ はそれぞれ点 $U$ と $\bar{O}$ の円周方向たわみ角 であり，悠密には，

$$
\varphi=\frac{R_{0}+e_{H}}{R_{0}} \bar{\theta}_{\bar{x}}-\frac{e_{H}}{R_{0}} \frac{\partial \bar{\theta}_{\bar{y}}}{\partial \theta}
$$

であるが， $e_{H}$ は $R_{0}$ に比較して無視できるほど小さい ものと考えて $\varphi=\bar{\theta}_{\bar{x}}$ としている.

したがって並列 $n$ 主桁, 横桁 $s$ 本を有する曲線桁橋全 体での節線力ベクトル $\{X\}$ と節点力ベクトル $\{\bar{X}\}$ と の関係は式 (13) から次式で与えられる(Fig. 6 参照).

$$
\{X\}=[A]\{\bar{X}\}
$$

ここに， $[A]$ は節線力と節点力の 変換行列であり， $\{X\},\{\bar{X}\},[A]$ の具体的内容については 付録 A-4 参 照. 同様に曲線桁橋全体での節線変位ベクトル $\{\delta\}$ と節 点変位ベクトル $\{\bar{\delta}\}$ との関係は, 式 (14)より次式で与 えられる。

$$
\{\delta\}=[B]\{\bar{\delta}\}
$$

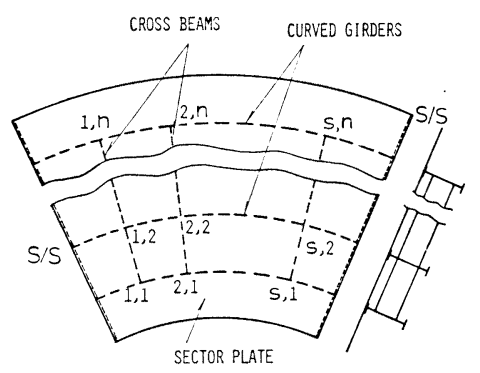

Fig. 6 Sequence Number of Connecting Points 
ここに， $[B]$ は節線変位と節点変位の変換行列であり， $\{\delta\},\{\bar{\delta}\},[B]$ の具体的内容については付録 A-5 参照.

以上で定義した節線変位ベクトル $\{\delta\}$ と節線力ベクト ル $\{X\}$ との関倸は, 式 (11) で求めた基本構の節線た わみ性行列 $\left[F_{m}\right]$ を用いて次式で与えられる.

$$
\{\delta\}=\left[f_{X X}\right]\{X\}
$$

$\left[f_{X X}\right]$ の具体的内容については付録 $\mathbf{A}-6$ 参照. 式 $(15 \cdot a) ，(16 \cdot a)$ および $(17 \cdot a)$ から節点変位べクトル $\{\bar{\delta}\}$ と節点力ベクトル $\{\bar{X}\}$ との関係は次式で与えられ ๖.

$$
\{\bar{\delta}\}=\left[\bar{f}_{X X}\right]\{\bar{X}\}
$$

ここに，

$$
\left[\bar{f}_{X X}\right]=[B]^{-1}\left[f_{X X}\right][A]
$$

式 (19) の $\left[\bar{f}_{X X}\right]$ は基本構の節点たわみ性行列である.

これまでに誘導した諸式を用いて以下の手順で結合力 （節点力）を求めることができる.

（a）基本系（X(0) 系） 基本構に外荷重 $\left\{X_{(0)}\right\}$ が 作用する系を FSM で解き, 横桁との結合点での節点変 位ベクトル $\left\{\bar{\delta}_{(0)}\right\}$ を求める（添字 $(0)$ は基本系である ことを示し，以下同種の添字はそれぞれの系を示す).

$$
\left\{\vec{\delta}_{(0)}\right\}=[B]^{-1}\left\{\delta_{(0)}\right\}
$$

(b) 第 1 系 $\left(\bar{X}_{(1)}\right.$ 系) 基本構に節点力 $\left\{\bar{X}_{(1)}\right\}$ だ けが働く系を第 1 系とよぶ. 第 1 系の節点変位ベクトル $\left\{\bar{\delta}_{(1)}\right\}$ と節点力ベクトル $\left\{\bar{X}_{(1)}\right\}$ との関係は, 基本構の 節点たわみ性行列 $\left[\bar{f}_{X X}\right]$ を用いて次式で表わされる.

$$
\left\{\bar{\delta}_{(1)}\right\}=\left[\bar{f}_{X X}\right]\left\{\bar{X}_{(1)}\right\}
$$

(c) 第 2 系 (横桁系, $\bar{X}_{(2)}$ 系) 横桁に節点力 $\left\{\bar{X}_{(2)}\right\}$ が働く系を第 2 系（横桁系）とし，式 (12) を用 いて横桁系の剛性方程式を組み立てる.

$$
\left\{\bar{X}_{(2)}\right\}=[\bar{K}]\left\{\bar{\delta}_{(2)}\right\}
$$

(d) 節点力ベクトル $\left\{\bar{X}_{(1)}\right\}$ を求めるために次の 2 式を用いる。

変位の適合条件: $\left\{\bar{\delta}_{(0)}\right\}+\left\{\bar{\delta}_{(1)}\right\}=\left\{\bar{\delta}_{(2)}\right\} \cdots(23)$

力のつり合い条件: $\left\{\bar{X}_{(1)}\right\}+\left\{\bar{X}_{(2)}\right\}=\{0\} \cdots(24)$ 式 (21) ( 24$)$ から次式のように節点力ベクトル $\left\{\bar{X}_{(1)}\right\}$ を求的ることができる.

$$
\left\{\bar{X}_{(1)}\right\}=-\left([I]+[\bar{K}]\left[\bar{f}_{X X}\right]\right)^{-1}[\bar{K}]\left\{\bar{\delta}_{(0)}\right\}
$$

式 (15・a) を用いれば，上式の $\left\{\bar{X}_{(1)}\right\}$ を節線力ベクト ル $\left\{X_{(1)}\right\}$ に変換できる.すなわち,

$$
\left\{X_{(1)}\right\}=[A]\left\{\bar{X}_{(1)}\right\}
$$

したがって，外荷重 $\left\{X_{(0)}\right\}$ とこの $\left\{X_{(1)}\right\}$ を同時に基本 構に作用させて解けば与系の解がえられる.

\section{（4）非合成曲線桁橋への適用}

この解析法を非合成の曲線桁橋に適用するときは，並 列曲線主桁だけからなる構造を基本構とみなし，曲線桁
の中立線に関する基本構の剛性方程式を組みたてればよ い.このとき扇形带板要素の節線荷重ベクトルをそのま ま荷重ベクトルとして用いることができる．結合力・支 点反力を求める手順は床版がある場合と全く同じであ る.このようにこの解析法は非合成曲線桁橋のような骨 組構造に対しても有効である.

\section{3. 数值計算例}

\section{（1）模型実験結果との比較}

例題 1 : Fig. 7 に示す曲線 4 主林模型橋 ${ }^{31)}$ の静的載 荷実験結果との比較を行う. Table 1 は,点 $\mathrm{A} \sim \mathrm{E}$ に集 中荷重 $(10 \mathrm{~kg})$ が載荷されるときの $\mathrm{B}_{2}, \mathrm{~B}_{4}$ 桁下面の円 周方向ひずみを示したものである. 理論值 1 は曲線直交 異方性板理論による值 ${ }^{6}$, , 理論值 2 は本解析法による值 (帯板数 12), 理論值 3 は実験者が示す解析法 ${ }^{31}$ による 值である.この表から本解析法による值が横桁の有無に かかわらず実験值に近いことがわかる.

例題 2 : Fig. 8 に示寸曲線 4 主桁模型橋(アクリル樹 脂製，実験詳細は文献 6) 参照) の静的載荷実験結果と の比較を行う. 荷重は矩形分布荷重, 載荷位置はスパン 中央断面の点 $\mathrm{A} \sim \mathrm{D}$, ひずみ測定断面は載荷点から $0.8^{\circ}$ 支承寄りの断面で, 各桁に対し Fig. 9 に示す 3 点のひ ずみを測定した. Fig. 10，11 はそれぞれ点 A, B に載 荷したときの円周方向ひずみ分布を示したものである が，横桁の有無にかかわらず実験值と理論值 (帯板数”8) はほぼ一致しており，本解析法の妥当性が本例によって も知られよう. Fig. 12 に点A載荷時の $\mathrm{G} 1$ 析のひずみ

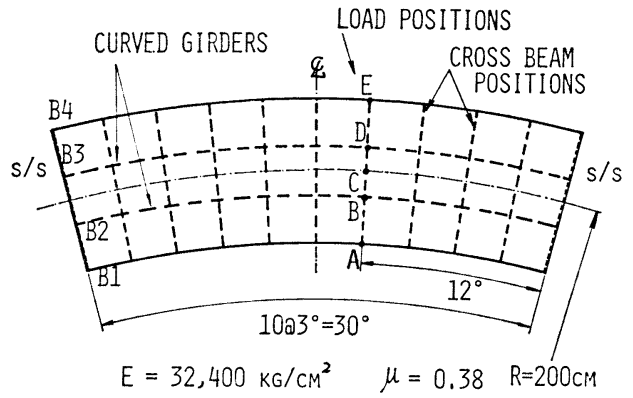

a) PLAN

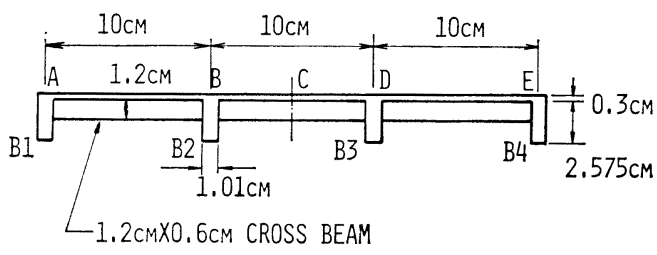

b) SECTION

Fig. 7 A Curved Girder Bridge Model (EX. 1) 
Table 1 Comparison between Experimental and Theoretical Strains

\begin{tabular}{|c|c|c|c|c|c|c|c|c|c|}
\hline \multirow{4}{*}{$\begin{array}{l}\text { Load } \\
\text { position }\end{array}$} & \multirow{4}{*}{ Strain at } & \multicolumn{8}{|c|}{ Tangential strain at midspan, in micro-strain } \\
\hline & & \multicolumn{4}{|c|}{ without cross beams } & \multicolumn{4}{|c|}{ with cross beams } \\
\hline & & \multirow{2}{*}{ Experiment } & \multicolumn{3}{|c|}{ Theory } & \multirow{2}{*}{ Experiment } & \multicolumn{3}{|c|}{ Theory } \\
\hline & & & 1 & 2 & 3 & & 1 & 2 & 3 \\
\hline A & $\begin{array}{l}\mathrm{B}_{2} \text { bottom } \\
\mathrm{B}_{4} \text { bottom }\end{array}$ & $\begin{array}{r}930 \\
94\end{array}$ & $\begin{array}{l}886 \\
348\end{array}$ & $\begin{array}{l}944 \\
202\end{array}$ & $\begin{array}{l}938 \\
211\end{array}$ & $\begin{array}{l}870 \\
140\end{array}$ & $\begin{array}{l}946 \\
278\end{array}$ & $\begin{array}{l}895 \\
239\end{array}$ & $\begin{array}{l}907 \\
250\end{array}$ \\
\hline $\mathrm{B}$ & $\begin{array}{l}\mathrm{B}_{2} \text { bottom } \\
\mathrm{B}_{4} \text { bottom }\end{array}$ & $\begin{array}{r}1062 \\
594\end{array}$ & $\begin{array}{l}841 \\
697\end{array}$ & $\begin{array}{r}1095 \\
602\end{array}$ & $\begin{array}{r}1089 \\
608\end{array}$ & $\begin{array}{l}760 \\
732\end{array}$ & $\begin{array}{l}762 \\
770\end{array}$ & $\begin{array}{l}828 \\
775\end{array}$ & $\begin{array}{l}800 \\
787\end{array}$ \\
\hline $\mathrm{C}$ & $\begin{array}{l}\mathrm{B}_{2} \text { bottom } \\
\mathrm{B}_{4} \text { bottom }\end{array}$ & $\begin{array}{l}795 \\
906\end{array}$ & $\begin{array}{l}721 \\
983\end{array}$ & $\begin{array}{l}808 \\
939\end{array}$ & $\begin{array}{l}807 \\
943\end{array}$ & $\begin{array}{r}732 \\
1062\end{array}$ & $\begin{array}{r}743 \\
1057\end{array}$ & $\begin{array}{r}757 \\
1085\end{array}$ & $\begin{array}{r}742 \\
1095\end{array}$ \\
\hline $\mathrm{D}$ & $\begin{array}{l}\mathrm{B}_{2} \text { bottom } \\
\mathrm{B}_{4} \text { bottom }\end{array}$ & $\begin{array}{r}527 \\
1325\end{array}$ & $\begin{array}{r}593 \\
1369\end{array}$ & $\begin{array}{r}552 \\
1392\end{array}$ & $\begin{array}{r}563 \\
1386\end{array}$ & $\begin{array}{r}634 \\
1380\end{array}$ & $\begin{array}{r}681 \\
1381\end{array}$ & $\begin{array}{r}678 \\
1412\end{array}$ & $\begin{array}{r}684 \\
1421\end{array}$ \\
\hline $\mathrm{E}$ & $\begin{array}{l}\mathrm{B}_{2} \text { bottom } \\
\mathrm{B}_{4} \text { bottom }\end{array}$ & $\begin{array}{r}284 \\
2160\end{array}$ & $\begin{array}{r}538 \\
1882\end{array}$ & $\begin{array}{r}302 \\
2292\end{array}$ & $\begin{array}{r}321 \\
2258\end{array}$ & $\begin{array}{r}513 \\
2060\end{array}$ & $\begin{array}{r}525 \\
1784\end{array}$ & $\begin{array}{r}501 \\
2067\end{array}$ & $\begin{array}{r}511 \\
2040\end{array}$ \\
\hline
\end{tabular}

Theory $1=$ Curvilinear Orthotropic Plate Theory (F.D.M.)

Theory $2=$ Proposed Method

Theory $3=$ Finite Difference Method+Energy Method

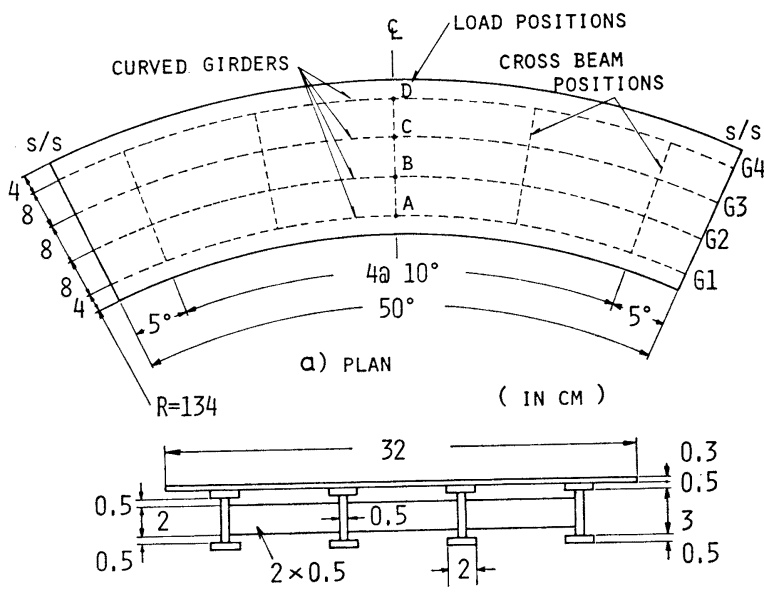

b) CROSS SECTION

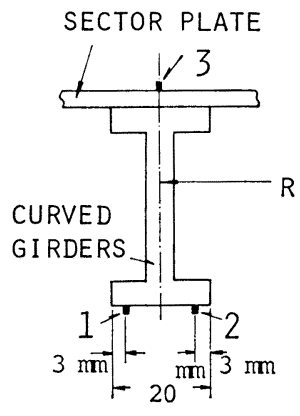

Fig. 9 Strain Gauge Positions

Fig. 8 A Curved Girder Bridge Model (EX. 2)

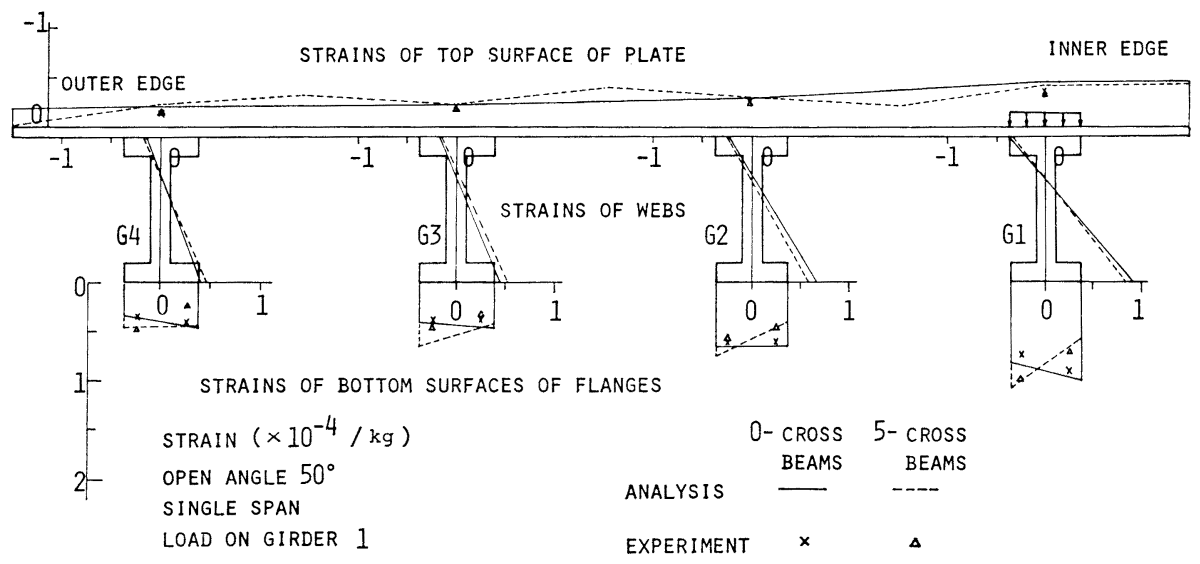

Fig. 10 Tangential Strains (Load on G 1) 


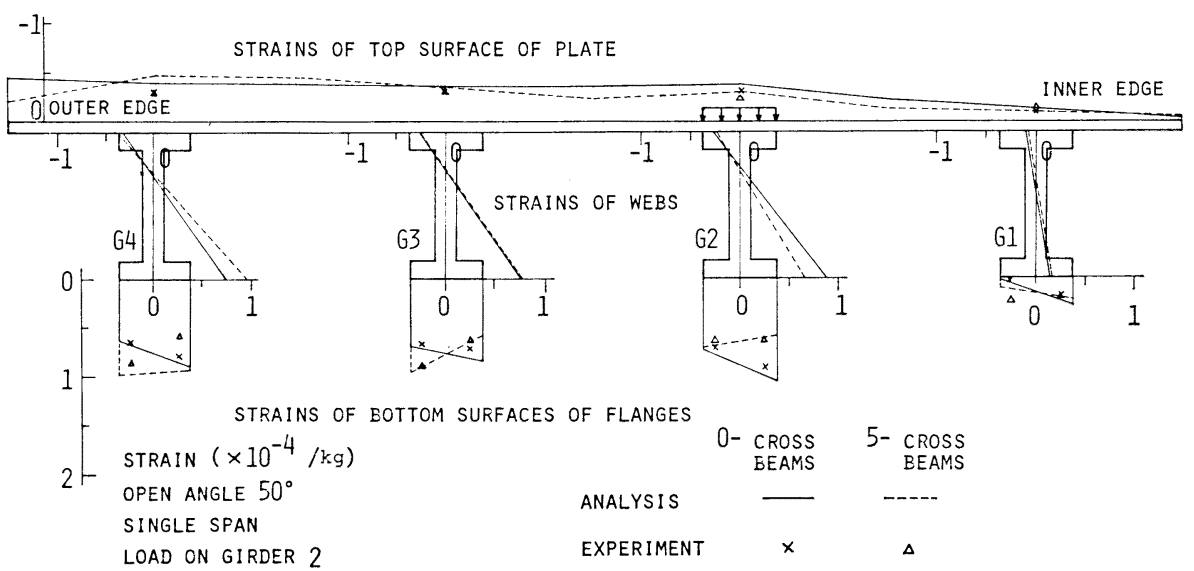

Fig. 11 Tangential Strains (Load on G 2)

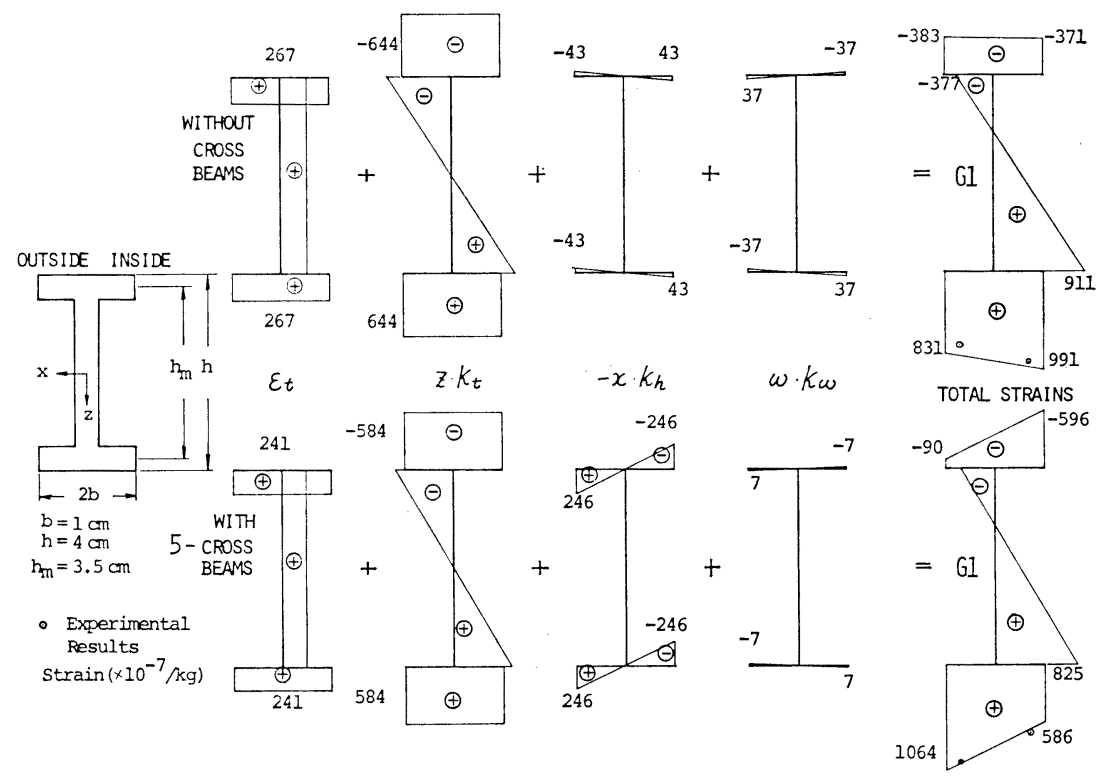

Fig. 12 Distributions of Tangential Strains of Girder 1 (Load on G 1)

分布を各ひずみ成分ごとに分けて表わした．これによれ ば，横桁がない構造では桁の鉛直軸まわりの曲げひずみ とそりひずみによって，G1 桁下フランジ下面のひずみ 分布は内端が外端より約 19\% 大きいこと, 一方横析が ある場合には，結合力によって桁の鉛直軸まわりの曲げ ひずみの方向が逆転し，内端が外端より約 $45 \%$ 小さく なることなどがわかる。

\section{（2） 2 主桁扇形板の特性}

Fig. 13 亿示寸扇形板が 2 直線辺を単純支持され，2 円弧辺を桁高 $d$, 桁幅 $b$ なる矩形断面曲線縁桁によって 弾性支持されている.このとき曲線桁と板とが偏心結合 される構造をCase A, 偏心がない構造を Case B とし, $\beta$ $=d / b$ と $r=b / h$ を変化させて数值計算を行った. 計算 にあたっては板厚 $h=1$, ヤング倸数 $E_{L}=1$, ポアソン

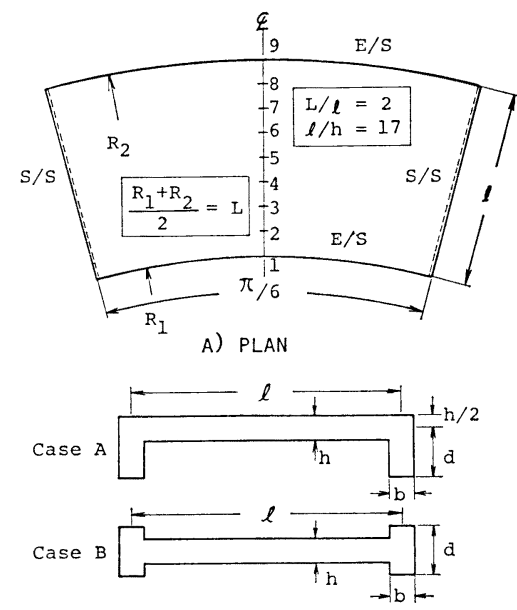

B) CROSS SECTION

Fig. 13 A Sector Plate with Stiffening Edge Beams 

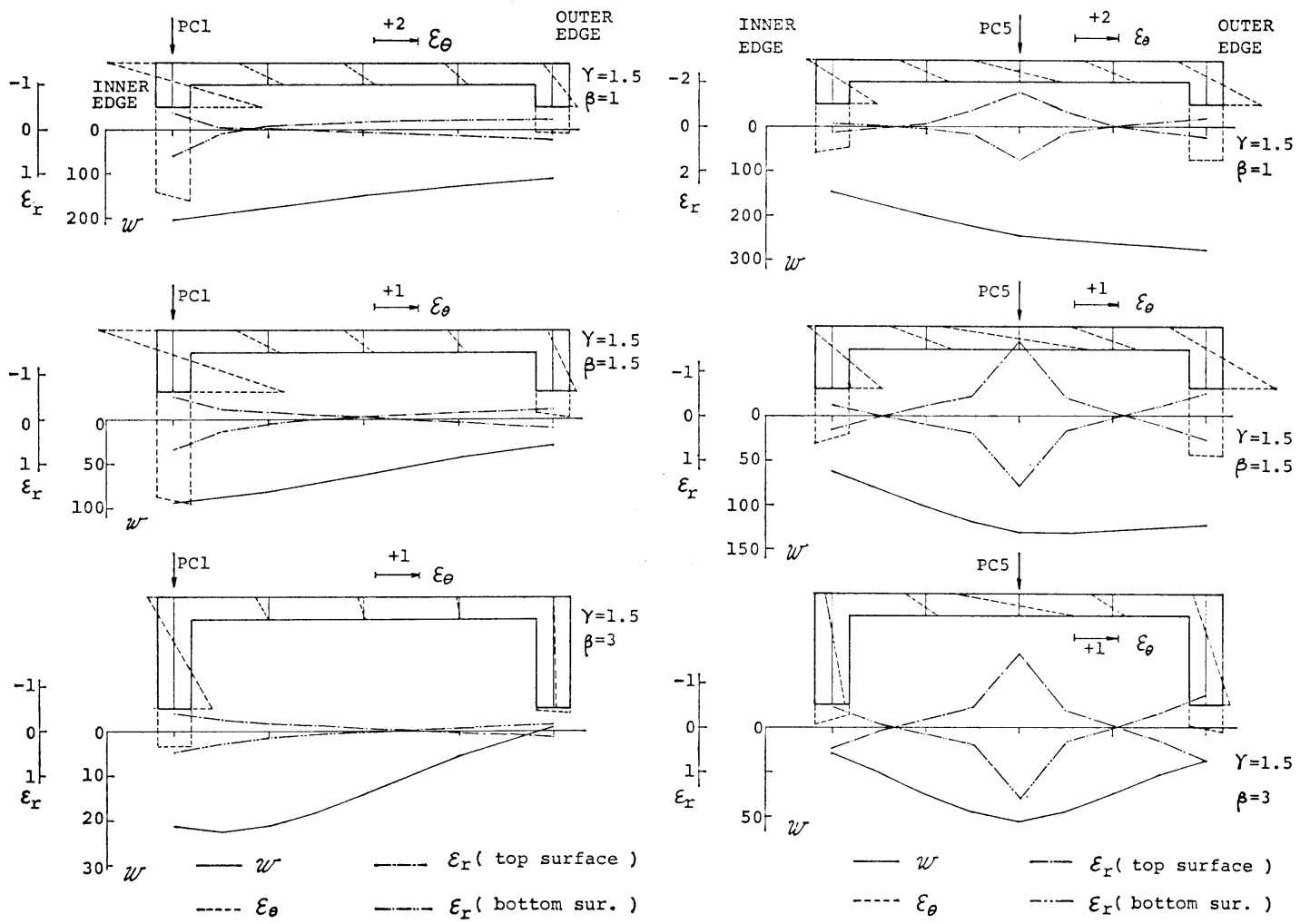

(a)

(b)
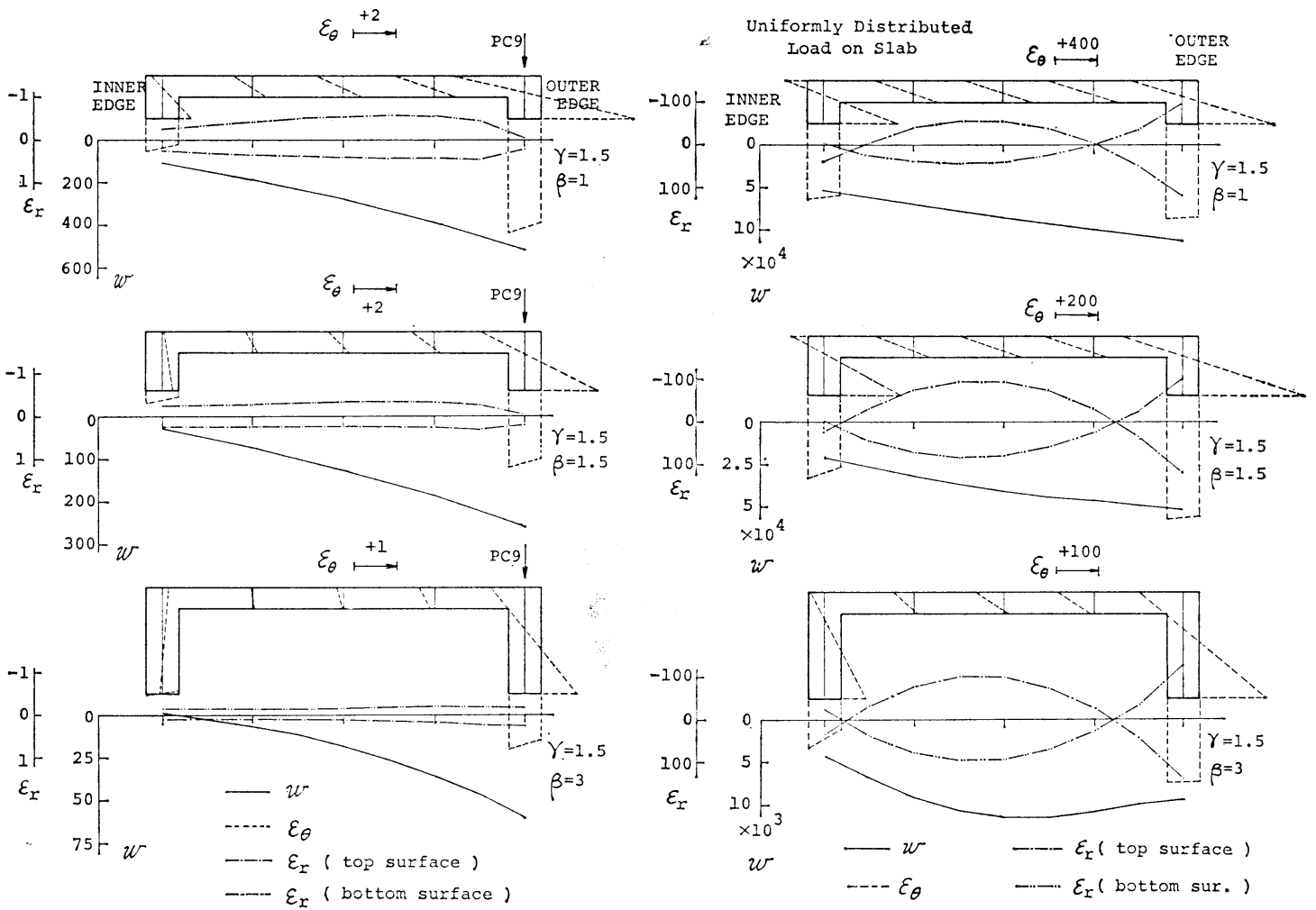

(c)

Fig. 14 Deflections and Strains at Midspan 

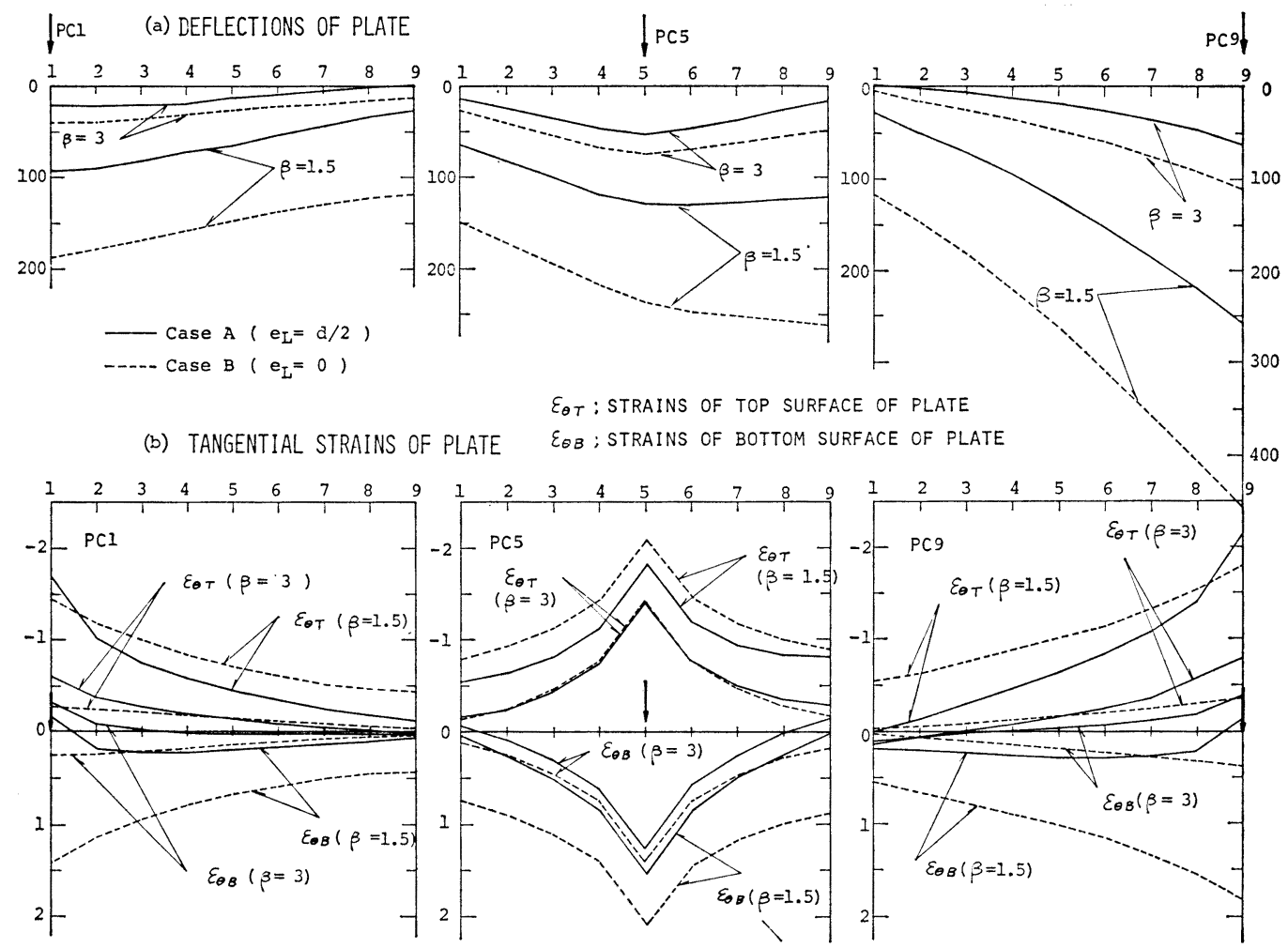

(c) RADIAL STRAINS OF PLATE
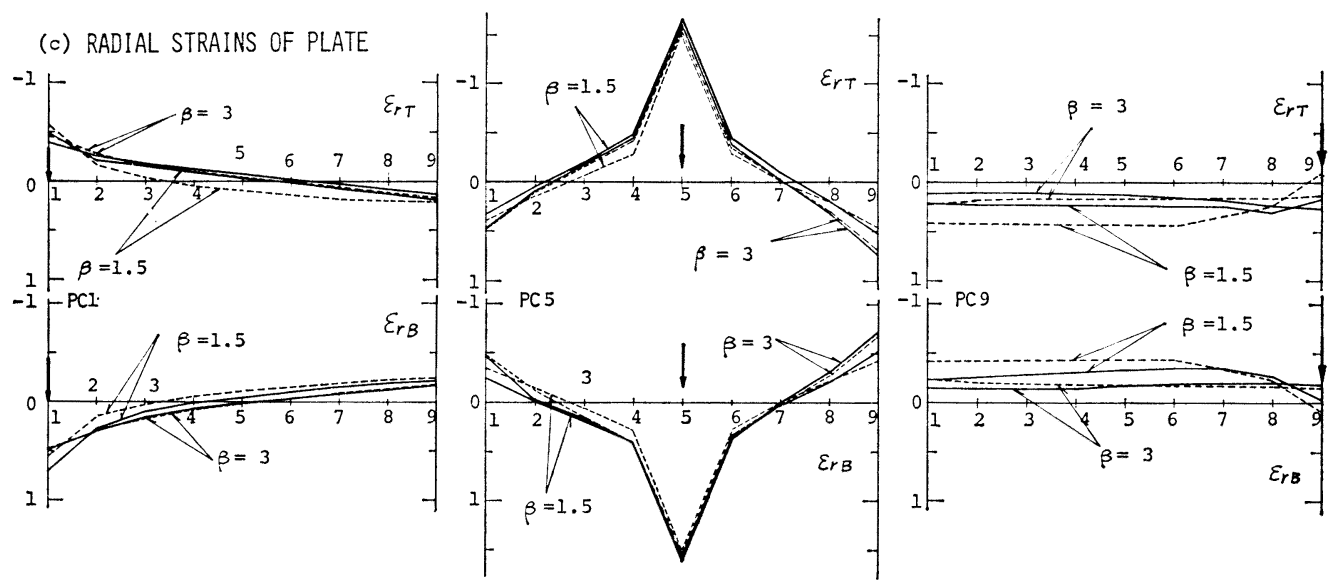

(d) TANGENTIAL STRAINS OF BOTTOM SURFACES OF EDGE BEAMS
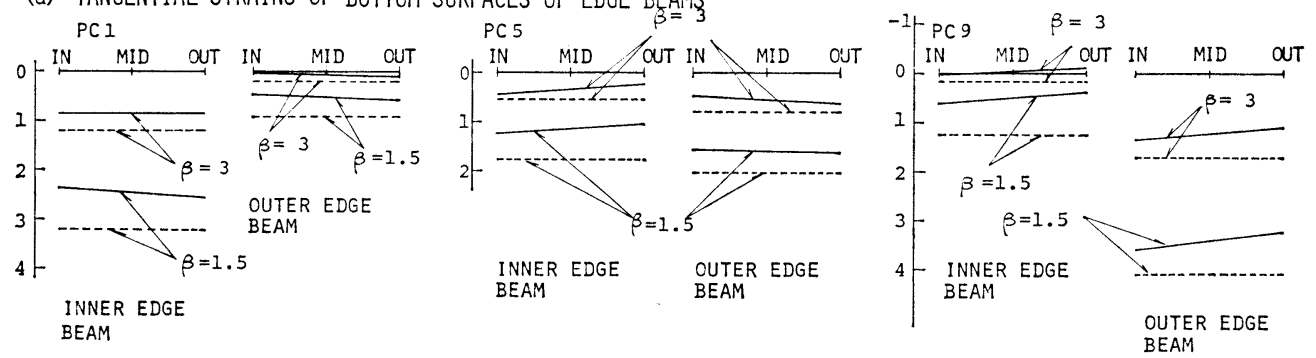

Fig. 15 Comparison between Case A and Case B 
比 $\nu=1 / 6$ とし, 曲線桁は 2 軸対称の中実矩形断面である から，桁の断面定数として $A_{L}, I_{x}, I_{z}, J_{L}$ を考慮した.

Fig. 14 は, Case A の構造の点 1, 5,9 に単位集中 荷重が作用するとき(Fig. 14 (a) 〜 (c)) と, 単位荷重 強度の等分布荷重が満載されるとき(同 (d)) の, スパ ン中央断面のたわみ $w$, 円周方向ひずみ $\varepsilon_{\theta}$, 半径方向ひ ずみ $\varepsilon_{r}$ を, $\gamma=1.5$ で $\beta=1,1.5$ および 3 の 3 ケースに 対しプロットしたものである.これらの図から知られる 特長を列記すれば次のとおりである（文中 PC 1 は点 1 載荷時を, UDL は等分布荷重満載時をさす).

a) $w$

PC 1 では桁高が小さいときには荷重の横分配が良好 であるが，桁高が大きくなるにつれて内析近傍では下に 凸のたわみ曲線となり横分配が悪くなる. PC 5, UDL では桁高が小さければ外桁の $\bar{w}$ が大きく，桁高が大き くなると点 5 付近の $w$ が最大となる. PC 9 では桁高 の大きさにかかわらず上に凸の曲線で，横分配はさほど 変らない.

\section{b) 板の $\varepsilon_{\theta}$}

PC 1, PC 9, UDL では桁高が大きくなるにつれて平 面応力による平面ひずみ成分が増大するため板は全体的 に圧縮ひずみを受けるようになる．PC 5 では曲げひず み成分が平面ひずみ成分より大きいため, 桁高が大きく ても板上下縁の圧縮ひずみと引張ひずみはほぼ等しい。

c) 板の $\varepsilon_{r}$

桁高・荷重位置にかかわらず曲げひずみ成分が平面ひ ずみ成分より大きいため，板上下縁の圧縮ひずみと引張 ひずみはほぼ等しい。

\section{d) 桁の $\varepsilon_{\theta}$}

桁のひずみ分布を各成分ごとに見れば，軸ひずみ成分 はすべて引張であり，桁の水平軸まわりの曲げひずみ成 分は, PC 9 の $\beta \geqq 2$ のとき内桁だけ上側引張となる が，他の場合は下側引張である. また Fig. 14 の桁下 面のひずみ分布に見られるようにそりねじり剛性を無視 できるような中実矩形断面であっても，板と桁の偏心結 合を考慮した場合には，鉛直軸まわりの曲げひずみ成分 によって桁下面のひずみ分布は一様にならず，しかも荷 重位置により鉛直軸まわりの曲げひずみ成分の正負の分 布が逆転することがわかる.

Case B の構造では, 板に平面応力が生じないことと， 桁に鉛直軸まわりの曲げモーメント，水平方向せん断力 および軸力が生じないことが, Case A の構造との基本 的な相違点であるが，いま $\gamma=1.5$ で $\beta=1.5$ および 3 の 2 ケースについて，たわみ・ひずみをスパン中央断面
で比較すれば Fig. 15 をらる.この図から，(1) たわ みと桁のひずみは Case B のほうが全体的に大きくなる こと，(2) $\mathrm{PC} 1, \mathrm{PC} 9$ での $\varepsilon_{\theta}$ には, Case A と B で著しい差異があること，(3） $\varepsilon_{r}$ の差はわずかである ことなどが知られる。

\section{4. 結語}

本研究は扇形床版・曲線主桁・横桁などの構成要素か らなる曲線桁橋の, 各構成要素間の偏心結合を考慮した 一解析法を提示したものである.

本解析法の主な特長として, 次の諸点があげられよ 5 .

（1）曲線主桁の剛性方程式をフーリエ級数展開によ り求めているので, FSM で誘導した扇形床版の節線剛 性方程式に, この曲線主桁の剛性方程式を重ね合わせる ことができる. したがって基本系では通常の FSM の解 析手順により所要の応力・変位を解くことができる.

（2）基本構の節点たわみ性行列と横桁の岡性行列を 用いて, 両構造を結合して与系を解析するため, 各構成 要素間の力学的相互作用が把握できる.

（3）横構・対傾構を有する構造では，これらを軸力 部材とみなし, その剛性方程式を FEM により求めれば 横桁同様に結合法を用いて, これらと基本構との偏心結 合を考慮した解析ができる。

(4) 非合成曲線桁橋のような骨組構造も特例として 取り扱いうる.

（5）扇形床版と曲線主桁との偏心結合を考慮してい るため, 床版の平面応力, 桁の鉛直軸まわりの曲げ・軸 力による影響を解析に取り入れることができる.

(6) 鉛直・水平方向に偏心結合量をもつ曲線格子箱 桁橋の解析にも適するよらに, 曲線主桁と横桁との偏心 結合量を考慮している.

(7) R C桁橋のように版と主・横桁が一体的に構築 される構造も, 床版の節線の位置に横桁要素の節点を配 置して両者の結合力を求めれば, 床版と横桁との偏心結 合を考慮して解析できよう。

模型実験結果との比較から判断されるようにこの解析 法は, 横桁取付位置近傍のひずみ分布に至るまで工学上 十分な精度の解を与えており，この種構造物の有用な一 解析法であることが知られる。

最後に本研究の数值計算には, 本学大型計算機センタ 一の FACOM 230-75 を使用したことを付記する. 
付 録

$[\mathbf{A}-1]$ 行列 $\left[\boldsymbol{A}_{m}\right]$ の内容（式 $\left.(7)\right)$

$\left[A_{m}\right]=$

$$
\left[\begin{array}{cccc}
\frac{S_{m}}{R_{o}} & -\frac{k_{m} S_{m}}{R_{o}} & \frac{e_{L} k_{m}{ }^{2} S_{m}}{R_{o}{ }^{2}} & -\frac{e_{L} S_{m}}{R_{o}} \\
0 & 0 & \frac{k_{m}{ }^{2} S_{m}}{R_{o}{ }^{2}} & -\frac{S_{m}}{R_{o}} \\
-\frac{k_{m}{ }^{2} S_{m}}{R_{o}{ }^{2}} & \frac{k_{m} S_{m}}{R_{o}{ }^{2}} & -\frac{e_{L} k_{m}{ }^{2} S_{m}}{R_{o}{ }^{3}} & \frac{e_{L} k_{m}{ }^{2} S_{m}}{R_{o}{ }^{2}} \\
0 & 0 & -\frac{k_{m}{ }^{2} S_{m}}{R_{o}{ }^{3}} & \frac{k_{m}{ }^{2} S_{m}}{R_{o}{ }^{2}} \\
0 & 0 & -\frac{k_{m} C_{m}}{R_{o}{ }^{2}} & \frac{k_{m} C_{m}}{R_{o}}
\end{array}\right]
$$

[A-2 $]$ 曲線桁の剛性行列 $\left[\boldsymbol{S}_{g m}\right]$ の各要素（式 $\left.(\mathbf{g})\right)$

$$
\begin{aligned}
& S_{g m(1,1)}=\left(\frac{D_{11}}{R_{o}}+\frac{k_{m}{ }^{4}}{R_{o}{ }^{3}} D_{33}\right) \frac{\alpha}{2} \\
& S_{g m(2,1)}=S_{g m(1,2)}=-\left(\frac{k_{m}}{R_{o}} D_{11}+\frac{k_{m}{ }^{3}}{R_{o}{ }^{3}} D_{33}\right) \frac{c^{\prime}}{2} \\
& S_{g m(2,2)}=\left(\frac{k_{m}{ }^{2}}{R_{o}} D_{11}+\frac{k_{m}{ }^{2}}{R_{o}{ }^{3}} D_{33}\right) \frac{\alpha}{2} \\
& S_{g m(3,1)}=S_{g m(1,3)}=\left(\frac{e_{L} k_{m}{ }^{2}}{R_{o}{ }^{2}} D_{11}-\frac{k_{m}{ }^{4}}{R_{o}{ }^{3}} D_{23}\right. \\
& \left.+\frac{e_{L} k_{m}{ }^{4}}{R_{o}{ }^{4}} D_{33}+\frac{k_{m}{ }^{4}}{R_{o}{ }^{4}} D_{34}\right) \frac{\alpha}{2} \\
& S_{g m(3,2)}=S_{g m(2,3)}=\left(-\frac{e_{L} k_{m}{ }^{3}}{R_{o}{ }^{2}} D_{11}+\frac{k_{m}{ }^{3}}{R_{o}{ }^{3}} D_{23}\right. \\
& \left.-\frac{e_{L} k_{m}{ }^{3}}{R_{o}{ }^{4}} D_{33}-\frac{k_{m}{ }^{3}}{R_{o}^{4}} D_{34}\right) \frac{c}{2} \\
& S_{g m(3,3)}=\left(\frac{e_{L}{ }^{2} k_{m}{ }^{4}}{R_{o}{ }^{3}} D_{11}+\frac{k_{m}{ }^{4}}{R_{o}{ }^{3}} D_{22}-\frac{2 e_{L} k_{m}{ }^{4}}{R_{o}{ }^{4}} D_{23}\right. \\
& -\frac{2 k_{m}{ }^{4}}{R_{o}{ }^{4}} D_{24}+\frac{e_{L}{ }^{2} k_{m}{ }^{4}}{R_{o}{ }^{5}} D_{33}+\frac{2 e_{L} k_{m}{ }^{4}}{R_{o}{ }^{5}} \\
& \text { - } \left.D_{34}+\frac{k_{m}{ }^{4}}{R_{o}{ }^{5}} D_{44}+\frac{k_{m}{ }^{2}}{R_{o}{ }^{3}} D_{55}\right) \frac{\omega}{2} \\
& S_{g m(4,1)}=S_{g m(1,4)}=\left(-\frac{e_{L}}{R_{o}} D_{11}+\frac{k_{m}^{2}}{R_{o}^{2}} D_{23}\right. \\
& \left.-\frac{e_{L} k_{m}{ }^{4}}{R_{o}{ }^{3}} D_{33}-\frac{k_{m}{ }^{4}}{R_{o}{ }^{3}} D_{34}\right) \frac{\alpha}{2} \\
& S_{g m(4,2)}=S_{g m(2,4)}=\left(\frac{e_{L} k_{m}}{R_{o}} D_{11}-\frac{k_{m}}{R_{o}^{2}} D_{23}\right. \\
& \left.+\frac{e_{L} k_{m}{ }^{3}}{R_{o}{ }^{3}} D_{33}+\frac{k_{m}{ }^{3}}{R_{o}{ }^{3}} D_{34}\right) \frac{\alpha}{2} \\
& S_{g m(4,3)}=S_{g m(3,4)}=\left(-\frac{e_{L}{ }^{2} k_{m}{ }^{2}}{R_{o}{ }^{2}} D_{11}-\frac{k_{m}^{2}}{R_{o}^{2}} D_{22}\right. \\
& +\frac{e_{L} k_{m}^{2}\left(1+k_{m}^{2}\right)}{R_{o}{ }^{3}} D_{23}+\frac{k_{m}^{2}\left(1+k_{m}^{2}\right)}{R_{o}^{3}} \\
& \text { - } D_{24}-\frac{e_{L^{2} k_{m}{ }^{4}}}{R_{o}{ }^{4}} D_{33}-\frac{2 e_{L} k_{m}{ }^{4}}{R_{o}{ }^{4}} D_{34}
\end{aligned}
$$

$$
\left.-\frac{k_{m}{ }^{4}}{R_{o}{ }^{4}} D_{44}-\frac{k_{m}^{2}}{R_{o}^{2}} D_{55}\right) \frac{\alpha}{2}
$$$$
S_{g m(4,4)}=\left(\frac{e_{L}^{2}}{R_{o}} D_{11}+\frac{D_{22}}{R_{o}}-\frac{2 e_{L} k_{m}^{2}}{R_{o}^{2}} D_{23}\right.
$$$$
-\frac{2 k_{m}^{2}}{R_{o}^{2}} D_{24}+\frac{e_{L}{ }^{2} k_{m}{ }^{4}}{R_{o}{ }^{3}} D_{33}+\frac{2 e_{L} k_{m}{ }^{4}}{R_{o}{ }^{3}}
$$$$
\text { - } \left.D_{34}+\frac{k_{m}{ }^{4}}{R_{o}{ }^{3}} D_{44}+\frac{k_{m}{ }^{2}}{R_{o}} D_{55}\right) \frac{\alpha}{2}
$$

ここに, $D_{11}=E_{L} A_{L}, \quad D_{22}=E_{L} I_{x}, D_{23}=E_{L} I_{x z}, D_{24}=$ $E_{L} C_{x}, \quad D_{33}=E_{L} I_{z}, \quad D_{34}=E_{L} C_{z}, \quad D_{44}=E_{L} C_{w}, \quad D_{55}=$ $G_{L} J_{L}$ である.

$[\mathbf{A}-3]$ 横林の剛性行列 $\left[\boldsymbol{K}_{a}\right],\left[\boldsymbol{K}_{b}\right]($ 式 (12))

$$
\begin{gathered}
{\left[K_{a}\right]=\frac{E_{R}}{L_{R}}} \\
{\left[\begin{array}{cccccc}
A_{R} & 0 & 0 & -A_{R} & 0 & 0 \\
0 & \frac{12 I_{\bar{y}}}{L_{R}{ }^{2}} & \frac{6 I_{\bar{y}}}{L_{R}} & 0 & -\frac{12 I_{\bar{y}}}{L_{R}{ }^{2}} & \frac{6 I_{\bar{y}}}{L_{R}} \\
0 & \frac{6 I_{\bar{y}}}{L_{R}} & 4 I_{\bar{y}} & 0 & -\frac{6 I_{\bar{y}}}{L_{R}} & 2 I_{\bar{y}} \\
-A_{R} & 0 & 0 & A_{R} & 0 & 0 \\
0 & -\frac{12 I_{\bar{y}}}{L_{R}{ }^{2}}-\frac{6 I_{\bar{y}}}{L_{R}} & 0 & \frac{12 I_{\bar{y}}}{L_{R}} & -\frac{6 I_{\bar{y}}}{L_{R}} \\
0 & \frac{6 I_{\bar{y}}}{L_{R}} & 2 I_{\bar{y}} & 0 & -\frac{6 I_{\bar{y}}}{L_{R}} & 4 I_{\bar{y}}
\end{array}\right]} \\
{\left[K_{b}\right]=\frac{G_{R} J_{R}}{L_{R}}\left[\begin{array}{rr}
1 & -1 \\
-1 & 1
\end{array}\right]}
\end{gathered}
$$

ここに, $L_{R}, E_{R}, G_{R}, A_{R}, I_{\bar{y}}$ および $J_{R}$ はそれぞれ横 桁の長さ, ヤング係数, せん断弾性係数, 断面積, $\bar{y}$ 軸 に関する断面 2 次 モーメントおよび純ねじり定数であ る.

[A-4] 行列 $\{\boldsymbol{X}\},\{\overline{\boldsymbol{X}}\},[\boldsymbol{A}]$ の内容 (式 $(15 \cdot \mathbf{a}))$

$$
\begin{aligned}
& \{X\}=\{\{Y\}\{Z\}\}^{T} \\
& \{Y\}=\left\{\left\{Y_{1}\right\} \cdots\left\{Y_{s}\right\}\right\}^{T}, \quad\{Z\}=\left\{\left\{Z_{1}\right\} \cdots\left\{Z_{s}\right\}\right\}^{T} \\
& \left\{Y_{1}\right\}=\left\{H_{1,1} V_{1,1} M_{1,1} \cdots H_{1, n} V_{1, n} M_{1, n}\right\}^{T}, \cdots, \\
& \left\{Y_{s}\right\}=\left\{H_{s, 1} V_{s, 1} M_{s, 1} \cdots H_{s, n} V_{s, n} M_{s, n}\right\}^{T^{\top}} \\
& \left\{Z_{1}\right\}=\left\{T_{1,1} \cdots T_{1, n}\right\}^{T}, \cdots,\left\{Z_{s}\right\}=\left\{T_{s, 1} \cdots T_{s, n}\right\}^{T} \\
& \{\bar{X}\}=\{\{\bar{Y}\}\{\bar{Z}\}\}^{T} \\
& \{\bar{Y}\}=\left\{\left\{\bar{Y}_{1}\right\} \cdots\left\{\bar{Y}_{s}\right\}\right\}^{T}, \quad\{\bar{Z}\}=\left\{\left\{\bar{Z}_{1}\right\} \cdots\left\{\bar{Z}_{s}\right\}\right\}^{T} \\
& \left\{\bar{Y}_{1}\right\}=\left\{\bar{N}_{1,1} \bar{V}_{1,1} \bar{M}_{\bar{y}_{1}, 1} \cdots \bar{N}_{1, n} \bar{V}_{1, n} \bar{M}_{\bar{y}_{1}, n}\right\}^{T}, \cdots, \\
& \left\{\bar{Y}_{s}\right\}=\left\{\bar{N}_{s, 1} \bar{V}_{s, 1} \bar{M}_{\bar{y} s, 1} \cdots \bar{N}_{s, n} \bar{V}_{s, n} \bar{M}_{\bar{y} s, n}\right\}^{T} \\
& \left\{\bar{Z}_{1}\right\}=\left\{\bar{M}_{\bar{x}_{1}, 1} \cdots \bar{M}_{\bar{x}_{1}, n}\right\}^{T}, \cdots, \\
& \left\{\bar{Z}_{s}\right\}=\left\{\bar{M}_{\bar{x} s, 1} \cdots \bar{M}_{\bar{x} s, n}\right\}^{T}
\end{aligned}
$$

添字のうち節線力と節点力の第 1 添字は円周方向の結合 点番号を示し，第 2 添字は半径方向の結合点番号を示す (Fig. 6).

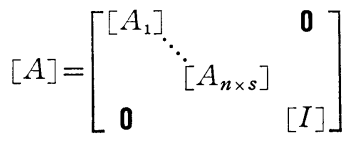




$$
\begin{aligned}
& {\left[A_{1}\right]=\cdots=\left[A_{n \times s}\right]=\left[\begin{array}{ccc}
1 & 0 & 0 \\
0 & 1 & 0 \\
-\left(e_{L}+e_{R}\right) & e_{H} & 1
\end{array}\right],} \\
& {[I]: \text { 単位行列 }}
\end{aligned}
$$

[A-5] 行列 $\{\boldsymbol{\delta}\},\{\overline{\boldsymbol{\delta}}\},[B]$ の内容 $($ 式 $(16 \cdot \mathbf{a}))$

$$
\begin{aligned}
& \{\delta\}=\{\{\zeta\}\{\varphi\}\}^{T} \\
& \{\zeta\}=\left\{\left\{\zeta_{1}\right\} \cdots\left\{\zeta_{s}\right\}\right\}^{T},\{\varphi\}=\left\{\left\{\varphi_{1}\right\} \cdots\left\{\varphi_{s}\right\}\right\}^{T} \\
& \left\{\zeta_{1}\right\}=\left\{u_{1,1} w_{1,1} \psi_{1,1} \cdots u_{1, n} w_{1, n} \psi_{1, n}\right\}^{T}, \cdots, \\
& \left\{\zeta_{s}\right\}=\left\{u_{s, 1} w_{s, 1} \psi_{s, 1} \cdots u_{s, n} w_{s, n} \psi_{s, n}\right\}^{T} \\
& \left\{\varphi_{1}\right\}=\left\{\varphi_{1,1} \cdots \varphi_{1, n}\right\}^{T}, \cdots,\left\{\varphi_{s}\right\}=\left\{\varphi_{s, 1} \cdots \varphi_{s, n}\right\}^{T} \\
& \{\bar{\delta}\}=\{(\bar{\zeta}\}\{\bar{\varphi}\}\}^{T} \\
& \{\bar{\zeta}\}=\left\{\left\{\bar{\zeta}_{1}\right\} \cdots\left\{\bar{\zeta}_{s}\right\}\right\}^{T},\{\bar{\varphi}\}=\left\{\left\{\bar{\varphi}_{1}\right\} \cdots\left\{\bar{\varphi}_{s}\right\}\right\}^{T}
\end{aligned}
$$

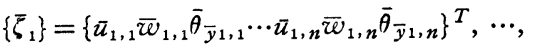

$$
\begin{aligned}
& \left\{\bar{\zeta}_{s}\right\}=\left\{\bar{u}_{s, 1} \bar{w}_{s, 1} \bar{\theta}_{\bar{y} s, 1} \cdots \bar{u}_{s, n} \bar{\omega}_{s, n} \bar{\theta}_{\bar{y} s, n}\right\}^{T}
\end{aligned}
$$

$$
\begin{aligned}
& \left\{\bar{\phi}_{1}\right\}=\left\{\bar{\theta}_{\bar{x}_{11}, 1} \cdots \bar{\theta}_{\bar{x}_{1}, n}\right\}^{T}, \cdots,\left\{\bar{\varphi}_{s}\right\}=\left\{\bar{\theta}_{\bar{x} s, 1} \cdots \bar{\theta}_{\bar{x} s, n}\right\}^{T} \\
& {[B]=\left[\begin{array}{cccc}
{\left[B_{1}\right]} & & & 0 \\
& \ddots & & \\
& {\left[B_{n \times s}\right]} & \\
0 & & & {[I]}
\end{array}\right]} \\
& {\left[B_{1}\right]=\cdots=\left[B_{n \times s}\right]=\left[\begin{array}{ccc}
1 & 0 & \left(e_{L}+e_{R}\right) \\
0 & 1 & -e_{H} \\
0 & 0 & 1
\end{array}\right]}
\end{aligned}
$$

ただし $e_{R}, e_{H}$ の值が結合点によって異なる場合には， それぞれの值を式 $(15 \cdot b),(16 \cdot b)$ の各行列の要素代代 大すればよい.

\section{$[A-6]$ 行列 $\left[f_{X X}\right]$ の内容 $($ 式 $(17 \cdot \mathbf{a}))$}

$$
\left[f_{X X}\right]=\left[\begin{array}{ll}
{\left[f_{Y Y}\right]} & {\left[f_{Y Z}\right]} \\
{\left[f_{Z Y}\right]} & {\left[f_{Z Z}\right]}
\end{array}\right]
$$

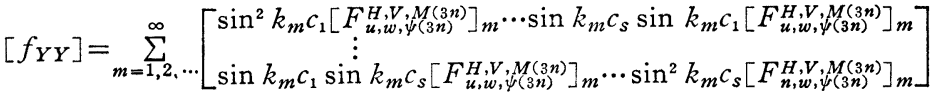

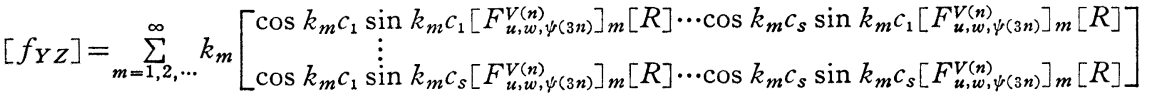

$$
\begin{aligned}
& {\left[f_{Z Y}\right]=\sum_{m=1,2, \cdots}^{\infty} k_{m}\left[\begin{array}{c}
\sin k_{m} c_{1} \cos k_{m} c_{1}[R]\left[F_{w(n)}^{H, W(3 n)}\right]_{m} \cdots \sin k_{m} c_{s} \cos k_{m} c_{1}[R]\left[F_{w(n)}^{H, W(3 n)}\right]_{m} \\
\sin k_{m} c_{1} \cos k_{m} c_{s}[R]\left[F_{w(n)}^{H, V, M(3 n)}\right]_{m} \cdots \sin k_{m} c_{s} \cos k_{m} c_{s}[R]\left[F_{w(n)}^{H, M(3 n)}\right]_{m}
\end{array}\right]} \\
& {\left[f_{Z Z}\right]=\sum_{m=1,2, \cdots}^{\infty} k_{m}^{2}\left[\begin{array}{c}
\left.\cos ^{2} k_{m} c_{1}[R]\left[F_{w w n}^{V(n)}\right]\right]_{m}[R] \cdots \cos k_{m} c_{s} \cos k_{m} c_{1}[R]\left[F_{w(n)}^{V(n)}\right]_{m}[R] \\
\vdots \\
\cos k_{m} c_{1} \cos k_{m} c_{s}[R]\left[F_{w(n)}^{V(n)}\right]_{m}[R] \cdots \cos ^{2} k_{m} c_{s}[R]\left[F_{w(n)}^{V(n)}\right]_{m}[R]
\end{array}\right]}
\end{aligned}
$$$$
[R]=\left[\begin{array}{ccc}
\frac{1}{r_{1}} & & 0 \\
& \ddots & \\
0 & \frac{1}{r_{n}}
\end{array}\right]
$$$$
c_{1} \cdots c_{s}: \text { 結合点位置の角距離 }
$$

$\left[F_{u, w, \psi}^{H, V}(3 n)\right]_{m}$ 注基本構の節線たわみ性行列 $\left[F_{m}\right]$ から 結合点のある節線 $1 \sim n$ の変位 $u, w, \psi$ に関する行要素 を抽出し, 結合点のある節線 $1 \sim n$ の力 $H, V, M$ 関 する列要素を抽出して組み立てることを示し，（）内の 数字は上が列数, 下が行数を示す. 他の行列 $F$ の添字 も同様の意味を表わす.

\section{参 考 文 献}

1) 竹下 淳: 極異方性板理論による曲線橋の解析について, 土木技術, 16 巻, 3 号, pp. 5 10, 昭和 36 年 3 月.

2) 芳村 仁：曲線直交異方性扇形平板の曲げについて，土 木学会論文集, 第 82 号, pp. 1 8, 昭和 37 年 6 月.

3) 奥村 勇: 曲線直交異方性扇形平板の階差法による解法, 土木学会論文集, 第 140 号, pp. 55 58, 昭和 42 年 4 月.

4) Heins, C.P. and R.L. Hails : Behavior of Stiffened Curved Plate Model, Proc. ASCE, Vol. 95, No. ST 11, pp. 2353 2370, Nov., 1969.

5) Cheung, Y.K. : The Analysis of Cylindrical Orthotropic Curved Bridge Decks, Publications IABSE, 29-II, pp. 41 52, 1969.

6）大塚久哲・吉村虎蔵：曲線直交異方性板理論による曲線 桁橋解析における換算剛度について, 九大工学集報, 第 48 巻, 第 5 号, pp. $579 \sim 586$, 昭和 50 年 10 月.

7）倉西 茂：曲線格子桁の解法, 土木学会論文集, 第 76 号, pp. $13 \sim 18$, 昭和 36 年 9 月.

8）山本 宏：円弧部材列を有する平面構造物に対するモー メント分配法, 土木学会論文報告集, 第 174 号, pp. 57 $\sim 72,1970$ 年 2 月.

9）稼農知徳：曲線格子桁の実用解析法, 土木学会諭文報告 集, 第 189 号, pp. 1 12, 1971 年 5 月.

10）渡辺 昇・稼農知德・藤井裕司：曲げねじれ剛性をもっ た曲線桁橋の剛性マトリックス法による解析, 土木学会 論文集, 第 218 号, pp. 1 8, 1973 年 10 月.

11）薄木征三・稼農知德：薄肉断面曲線材の変形法による解 析, 土木学会論文報告集, 第 235 号, pp. 29 39, 1975 年 3 月.

12）小西一郎 - 小松定夫：薄肉曲線桁の基礎理論, 土木学会 論文集, 第 87 号, pp. 35 46, 昭和 37 年 11 月.

13）小西一郎 - 小松定夫：単純支持曲線桁橋の立体的解析, 土木学会論文集, 第 90 号, pp. 11 26, 昭和 38 年 2 月.

14）小西一郎 - 小松定夫：薄肉連続曲線桁橋の立体的解析, 土木学会論文集, 第 91 号, pp. 13 23, 昭和 38 年 3 月.

15）小松定夫：曲線並列桁橋の実用計算式，土木学会論文集， 第 93 号, pp. 1 9, 昭和 38 年 5 月.

16）倉西 茂：一般薄肉咪面の曲りばりの解析, 土木学会論 文集, 第 108 号, pp. $7 \sim 12$, 昭和 39 年 8 月.

17）深沢泰晴：薄肉曲線材の静力学的解析に関する基礎的理 論, 土木学会論文集, 第 110 号, pp. $30 \sim 51$, 昭和 39 年 10 月.

18）西野文雄・深沢泰晴：ひずみ場の仮定に基ゔく薄肉曲が りばりの静的挙動の定式化, 土木学会論文報告集, 第 247 号, pp. 9 20,1976 年 3 月.

19）平井一男：種々の移動荷重をうけるはり構造の基礎方程 
式とその応用, 土木学会論文集, 第 90 号, pp. 29〜36, 昭和 38 年 2 月.

20）吉村虎蔵・平井一男：ランガー桁の動的解析, 土木学会 論文集, 第 101 号, pp. 1 14, 昭和 39 年 1 月.

21）平井一男：結合法による弾性支承を有する連続ばりの動 的解析, 土木学会論文集, 第 104 号, pp. 1 8, 昭和 39 年 4 月.

22）吉村虎藏・平井一男：はりあるいはラーメンとトラスと を組合わせた構造物の動的および静的解析法について, 土木学会論文集, 第 116 号, pp. 1 7, 昭和 40 年 4 月.

23）吉村虎藏・平井一男：単位構造物の結合による骨組の動 的解析, コンピニーターによるマトリックス構造解析法 講習会テキスト, 日本鋼構造協会, 昭和 46 年 3 月.

24) Yonezawa, H.: Moments and Free Vibrations in Curved Girder Bridges, Proc. ASCE, Vol. 88, No. EM 1, pp. 1 21, Feb., 1962.

25）山崎徳也・㯪木 武・金子忠男：連続円形曲りばりにて 弾性支持される扇形板の解法, 九大工学集報, 第 41 巻, 第 6 号, pp. 915 923, 昭和 43 年 12 月.

26) Yamasaki, T. and T. Kaneko: Free Vibration of Circular Ring Sector Plate with Stiffening Beams, Proc. the 19th Japan National Congress for Applied Mechanics, 1969, pp. 147 152, Dec., 1970.

27) Yamasaki, T. and T. Kaneko: Analysis of Curvilinear Orthotropic Circular Ring Sector Plates with two Opposite Circular Edges Stiffened with Frames,
Proc. the 20th Japan National Congress for Applied Mechanics, 1970,pp. 161 174, Dec., 1971.

28) Otsuka, H. : Finite Difference Analysis of Circular Ring Sector Plates Supported by Edge-Beams, Proc. JSCE, No. 220, pp. 107 115, Dec., 1973.

29）大塚久哲 - 吉村虎蔵：差分法による周辺弾性支持曲線直 交異方性扇形平板の解析, 九大工学集報, 第 47 巻, 第 4 号, pp. 413 420, 昭和 49 年 9 月.

30）韮沢憲吉：曲り梁と曲線スラブからなる構造の解析につ いて, 北大工学部研究報告, 第 68 号, pp. 1 10, 昭和 48 年 9 月.

31) Buragohain, D.N. and S.B. Agrawal : Discrete Analysis of Curved Slab-Beam Systems, Publications IABSE, 34-II, pp. 19 37, 1974.

32) Cheung, M.S. and Y.K. Cheung : Analysis of Curved Box Girder Bridges by Finite Strip Method, Publications IABSE, 31- I, pp. 1 19, 1971.

33）大塚久哲 - 吉村虎蔵・彦坂 熙 $\cdot$ 藤津卓司: 有限带板法 による中間隔壁をもつ曲線箱析橋の解析, 九大工学集報, 第 49 巻, 第 2 号, pp. $67 \sim 74$, 昭和 51 年 3 月.

34）阪神高速道路公団: 鋼構造物設計基準, pp. $44 \sim 48$, 昭和 49 年 5 月.

35）彦坂 熙·内谷 保・大塚久哲：差分法と剛性法の垪用 による斜角支持曲線桁橋の解析, 九大工学集報, 第 49 巻, 第 3 号, pp. $247 \sim 252$, 昭和 51 年 6 月.

(1976.5.13 - 受付) 